Original Article

\title{
ANTIOXIDANT, PTP 1B INHIBITION AND A-AMYLASE INHIBITION PROPERTY AND GC-MS ANALYSIS OF METHANOLIC LEAVES EXTRACT OF ACHYRANTHES ASPERA AND CATHARANTHUS ROSEUS OF NEPAL
}

\author{
KARKI YASHODA ${ }^{1}$, KHADKA DEEGENDRA ${ }^{2}$, SUBBA BIMALA ${ }^{*}$
}

${ }^{1}$ Central Department of Chemistry, Tribhuvan University, Kathmandu, Nepal, ${ }^{2}$ Nepal Academy of Science and Technology, Kathmandu, Nepal

Email: bimalasubba@gmail.com

Received: 13 Dec 2020, Revised and Accepted: 15 Feb 2021

\begin{abstract}
Objective: The present study was designed to study phytochemicals and biological activities of the methanolic extracts of two traditional medicine plants Achyranthes aspera and Catharanthus roseus of Nepalese origin.

Methods: Plant extracts were prepared by cold percolation method. Antioxidant activity, brine shrimp lethality assay, and analysis of phytochemical constituents were carried out using standard methods. The dinitro salicylic acid (DNS) method was used to study the inhibition effect of extracts on $\alpha$-amylase enzyme. Furthermore, PTP 1B inhibitory activity was evaluated using $p$-nitrophenyl phosphate ( $p$-NPP) as substrate.

Results: Phytochemical analysis showed the presence of phytochemicals like alkaloids, flavonoids, glycosides, reducing sugars, etc. in both plants. Brine shrimp lethality assay suggested the presence of pharmacologically active compounds. Total phenolic content and total flavonoid content of $C$. roseus were found to be higher with $73.21 \mathrm{mg} \mathrm{GAE} / \mathrm{g}$ and $33.15 \mathrm{mg} \mathrm{Q} / \mathrm{g}$ respectively than that of $A$. aspera, which was found to be $57.09 \mathrm{mg} \mathrm{GAE} / \mathrm{g}$ and $28.96 \mathrm{mg} \mathrm{Q} / \mathrm{g}$ respectively. Similarly, the $\alpha$-amylase inhibition of $A$. aspera and C. roseus was found to be $97.60 \pm 1.11 \mu \mathrm{g} / \mathrm{ml}$ and $94.05 \pm 1.18$ $\mu \mathrm{g} / \mathrm{ml}$ comparative with $\mathrm{IC}_{50} 68.13 \pm 0.46 \mu \mathrm{g} / \mathrm{ml}$ of standard acarbose. Protein tyrosine phosphatase 1B (PTP1B) inhibition showed IC 50 for A. aspera and $C$. roseus to be $48.72 \pm 0.46$ and $50.21 \pm 1.03 \mu \mathrm{g} / \mathrm{ml}$, respectively. Qualitative GC-MS analysis of both plant hexane fractions showed acid and ester type of phytoconstituents.
\end{abstract}

Conclusion: These results suggested that both plants i. e A. aspera and C. roseus, Nepal origin showed biological activity by targeting multiple drug targets which justifies their traditional uses.

Keywords: Achyranthes aspera, Catharanthus roseus, Antioxidant, Total phenolic content, Total flavonoid content, $\alpha$-amylase inhibition, PTP1B inhibition, GC-MS

(C) 2021 The Authors. Published by Innovare Academic Sciences Pvt Ltd. This is an open access article under the CC BY license (https://creativecommons.org/licenses/by/4.0/) DOI: https://dx.doi.org/10.22159/ijpps.2021v13i4.40490. Journal homepage: https://innovareacademics.in/journals/index.php/ijpps.

\section{INTRODUCTION}

Diabetes mellitus is a group of metabolic diseases which is characterized by chronic hyperglycemia resulting from defects in insulin secretion, insulin action, or both [1]. The classical classification of diabetes as proposed by the American Diabetes Association in 1997 as type 1 , type 2 , other specific types, and gestational diabetes. Normally when there is an elevated level of glucose in the bloodstream, the pancreas releases insulin which then binds a membrane protein of a cell and causes a series of reactions that induce glucose transporters to move into the membrane and facilitate the movement of glucose into the cell $[2,3]$. Type 2 Diabetes (T2D) is characterized by an increase in insulin resistance and decreased betacell function and chronic hyperglycemia $[4,5]$. One of the control pathways for postprandial hyperglycemia in diabetic patients is the inhibition of the activity of $\alpha$-amylase and PTP 1B enzymes.

Protein tyrosine phosphatase 1B (PTP1B) is a negative regulator of insulin receptor signaling [6]. PTP 1B dephosphorylates and inactivates insulin receptor (IR), thereby switching off insulin signaling. During the combination of insulin and its receptor, PTP1B directly catalyzes the dephosphorylation of the phosphorylated tyrosine residues, insulin receptor, and insulin receptor substrates to negatively regulate insulin signal transduction. High expression of PTP1B influences the activity of Protein Tyrosine Kinases, which results in insulin failing to combine with IR, induces insulin resistance and leptin resistance, and causes T2D and obesity $[7,8]$. PTP 1B inhibition has emerged as a validated therapeutic target for the treatment of T2D and related metabolic abnormalities. Inhibition of digestive enzymes, alpha-amylase is also one of the effective methods for the control of the blood glucose level (postprandial hyperglycemia) in diabetes mellitus.
Natural products-based therapeutic approaches provide a fruitful source for searching for safe, effective, and relatively inexpensive new remedies for diseases [9]. Instead of using the side effects causing chemical drugs, the ancient medicine could be explored to identify the novel drug formulations that are more effective with lesser side effects and also cheaper cost. The active compound that is responsible for the pharmacological effect could be found very easily and also commercialized as a drug product itself with proper approval from the respective organizations [10]. Therefore, natural products are considered as important sources for new drugs or lead optimization for PTP1B inhibition and digestive enzymes inhibition, for the management of diabetes and obesity [11, 12]. In Nepal, about 16001900 species of plants are commonly used in traditional medicinal practices. Only a few of them are explored scientifically [13-15].

Achyranthes aspera Linn. Belongs to the amaranthaceae family [16]. The major chemical constituents are carbohydrates, protein, glycosides, alkaloids, tannins, saponins, flavonoids, lignin, etc. [17]. It is known for its uses as antimicrobial and antidiabetic, anti-phlegmatic, antiperiodic, diuretic, like toothbrush, mildly astringent, for the cure of night blindness, for treatment of malarial fever, anti-peroxidative, abortifacient, anti-leprotic, in treatment of asthma, cough, piles, dropsy, oedema and also for the cure of bites of a poisonous snake. It is used to cure scabies, rheumatism, and hemorrhoids [18-20].

Catharanthus roseus L. (G.) Don belongs to the Apocynaceae family. Detailed phytochemical studies showed several highly glycosylated flavonoids, mainly quercetin, kaempferol, and isorhamnetin derivatives. Other classes of phenolic compounds, namely benzoic acids, and phenylpropanoids have also been described [21]. It is known for its uses as antileukemic and antimutagenic, antioxidant, antidiabetic, antimicrobial, for improving blood circulation, as 
vasodilatory, transient depressor, to kill some intestinal parasites. It possesses mild antibiotic effects and is antihypertensive [10, 22].

Many research articles had been published reporting the biological activities of these plants. The chemical constituents of the plants are highly influenced by the variation in genetic, geographical, and seasonal factors as well as the developmental stages of the concerned plant and their parts/tissues. Unlike synthetic drugs, which usually contain a single active compound targeting a specific drug target, plant extracts may contain various active ingredients aiming at multiple drug targets.

Therefore, taking account of these reports, the present study aims to quantify the polyphenols and flavonoids in the methanolic extract from leaves of $A$. aspera and $C$. roseus to determine their antioxidant potential and to evaluate its inhibitory properties on the $\alpha$-amylase and PTP1B activities as well as their GC-MS analysis.

\section{MATERIALS AND METHODS}

Collection of plant materials and preparation of methanolic extract

The leaves of $A$. aspera and $C$. roseus were collected from Kavre district and identified at the Central Department of Botany, Kirtipur. Leaves were cleaned, chopped into small pieces, and shade dried for 10-15 d. Then it was ground into a powder and stored. Then methanolic leaves extract of both the plants was prepared by cold percolation method.

\section{Chemicals and reagents}

The chemicals used in this study were methanol (Merck, Germany), porcine pancreatic $\alpha$-amylase, 2,2-diphenyl-1-picrylhydrazyl (DPPH), and ascorbic acid, PTP1B (human, recombinant) dithiothreitol (DTT), para-Nitrophenylphasphate ( $p$-NPP) were purchased from Sigma-Aldrich, USA. All additional chemicals used in this research work were of the commercially available analytical grade.

\section{Phytochemical screening}

Phytochemicals present in both the plant extracts were identified by various color reactions with different reagents based on standard protocol along with some required modifications according to our laboratory facility $[23,24]$.

\section{Brine shrimp lethality assay}

This assay was performed according to the procedure given by Pisutthanan et al. [25, 26].

\section{Total phenolic content and total flavonoid content}

Total phenolic content in plant extract was calculated by FolinCiocalteu Colorimetric method based on oxidation-reduction reaction, whereas Total Flavonoid Content was determined by Aluminium Chloride Colorimetric Assay [26, 27].

\section{Antioxidant assay}

The ability of plant samples to scavenge 1,1-diphenyl-2-picrylhydrazyl (DPPH) free radicals was estimated by the method as described by Paudel et al. [28, 29].

\section{Alpha-amylase inhibition assay}

Dinitrosalicyclic acid (DNS) method was used with certain modifications to determine the effect of crude extracts on $\alpha$-amylase inhibition [30, 31].

\section{Protein tyrosine phosphatase 1B inhibition assay}

PTP 1B inhibitory activity was evaluated using $p$-nitrophenyl phosphate ( $p$-NPP) as a substrate following a standard protocol with certain modifications $[8,32,33]$.

\section{GC-MS analysis of hexane fraction}

Further fractionation of methanol extract of both samples was done to get hexane fraction, chloroform fraction, and ethyl acetate fraction. Then the phytochemicals present in the hexane extract were identified by using GC-MS QP 2010.

\section{RESULTS AND DISCUSSION}

\section{Phytochemical screening}

The results obtained from the phytochemical screening indicating the presence and absence of different types of phytoconstituents are tabulated below in table 1 .

Table 1: Phytoconstituents of $A$. aspera and $C$. roseus

\begin{tabular}{llll}
\hline S. No. & Phytochemicals & \multicolumn{2}{l}{ Results } \\
\cline { 3 - 4 } & & AA & CR \\
\hline 1. & Alkaloids & + & + \\
2. & Flavonoids & + & + \\
3. & Terpenoids & + & + \\
4. & Coumarins & + & + \\
5. & Glycosides & + & + \\
6. & Quinones & + & + \\
7. & Reducing sugars & + & + \\
8. & Polyphenols & + & + \\
9. & Saponins & & + \\
\hline
\end{tabular}

Where $(+)=$ Present and $(-)=$ Absent

Almost all tested phytochemicals were found in both plant extracts except coumarin in $A$. aspera. The result is well supported by previously reported results of these plants [17, 34, 35]. Plants having vitamins (C, E), carotenoids, flavonoids (flavones, isoflavonones, flavonones, anthocyanins, and catechins), and polyphenols (ellagic 7 acid, gallic acid, and tannins) had been reported with their remarkable antioxidants activity, and alpha-amylase inhibitory activity [36]. Berberine, papaverine, 2-arylbenzofuransare, cinnamic acid, flavonoids, terpenes, proteoglycan, quinolone, steroids, N-or Scontaining compounds, phenolics, etc. are some natural products that have been reported with PTP1B enzyme inhibition action [11].

\section{Brine shrimp bioassay}

Results obtained from the brine shrimp lethality assay are presented in table 2 .

Table 2: Calculation of $\mathrm{LC}_{50}$ value of $A$. aspera and $C$. roseus leaves

\begin{tabular}{lll}
\hline S. No. & Plant extracts (methanolic) & LC $_{50}$ value \\
\hline 1. & A. aspera & $681.29 \mu \mathrm{g} / \mathrm{ml}$ \\
2. & C. roseus & $464.16 \mu \mathrm{g} / \mathrm{ml}$ \\
\hline
\end{tabular}

$\mathrm{IC}_{50}$ values are expressed as mean $\pm \mathrm{SD}(\mathrm{n}=3)$

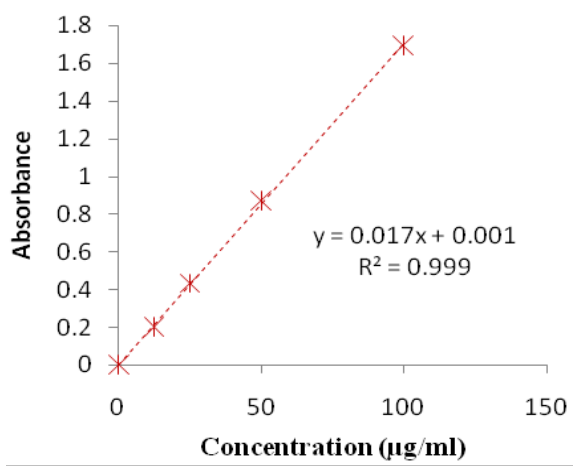

Fig. 1: Calibration curve of gallic acid

The methanolic extract of $A$. aspera and $C$. roseus were found to be toxic against brine shrimps as shown by their $\mathrm{LC}_{50}$ values of 681.29 $\mu \mathrm{g} / \mathrm{ml}$ and $464.16 \mu \mathrm{g} / \mathrm{ml}$, respectively, much below the accepted maximum potential value of $1000 \mu \mathrm{g} / \mathrm{ml}$. These results showed the 
presence of pharmacologically active compounds in the methanol fraction of both plants. Literature survey revealed the cytotoxic activity $C$. roseus and $A$. aspera, where superior results were reported than the results found here [37, 38]. This can be attributed due to the variation in altitude of plants, extraction procedure, etc.

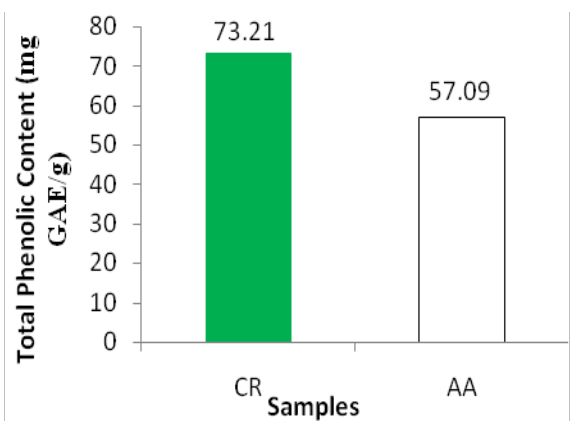

Fig. 2: TPC values of both samples Where $\mathrm{CR}=\boldsymbol{C}$. roseus and AA $=$ A. aspera

The concentration of gallic acid at the different absorbance of plant extracts was used to evaluate the total phenolic content of the plant extracts, which is shown in fig. $1 \& 2$.

A slightly higher concentration of phenols was measured in methanolic fraction of $C$. roseus than that of $A$. aspera fraction i.e. $73.21 \mathrm{mg} \mathrm{GAE} / \mathrm{g}$ and $57.09 \mathrm{mg} \mathrm{GAE} / \mathrm{g}$, respectively.

The literature revealed that TPC ranged from $8.18 \pm 1.61$ to $21.46 \pm 2.39 \mathrm{mg} \mathrm{GAE} / \mathrm{g}$ for methanolic extract of $C$. roseus [39]. Also, TPC extracted from its shoots in different solvent systems were in the ranges 3.2 to $8.5 \mathrm{GAE}$ (g/100g per dry matter) [39]. Another study showed $A$. aspera Linn. Possessed phenol constituent's $9.16 \pm 0.84 \mathrm{mg} / \mathrm{g}$ in the leaves of methanolic extract [41].

\section{Total flavonoid content}

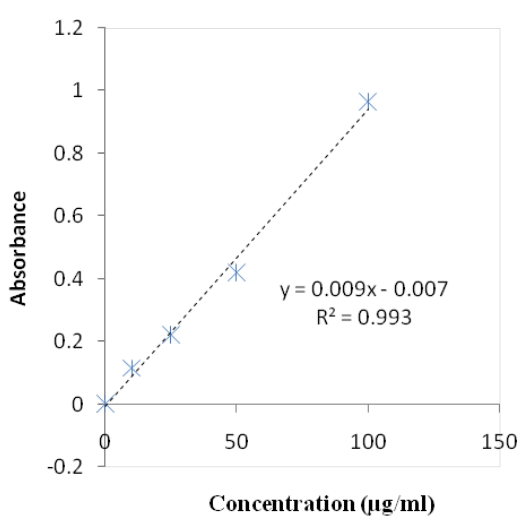

Fig. 3: Calibration curve of quercetin

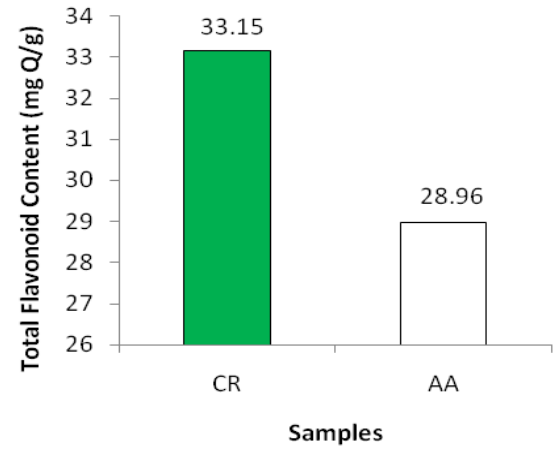

Fig. 4: TFC of samples, CR and AA

The concentration of quercetin at the different absorbance of plant extracts was used to evaluate the total flavonoid content of the plant extracts, which is shown in fig. $3 \& 4$.

A slightly higher concentration of flavonoid was measured in methanolic fraction of $C$. roseus than that of $A$. aspera fraction i.e. $33.15 \mathrm{mg} \mathrm{Q} / \mathrm{g}$ and $28.96 \mathrm{mg} \mathrm{Q} / \mathrm{g}$, respectively.

The literature revealed that methanolic extract of leaves of hexaploid plants of A. aspera Linn. had the flavonoid $78.36 \pm 1.63 \mathrm{mg} / \mathrm{g}[40]$. Roots contained $8.3 \mathrm{mg} / \mathrm{g}$ and $13.5 \mathrm{mg} / \mathrm{g}$ of QE respectively [41]. TFC extracted from $C$. roseus shoots in different solvent systems were in the ranges 1.8 to 5.4 (g/100g per dry matter). $100 \%$ methanolic extract of it showed the highest TFC $19.8 \mathrm{~g} / 100 \mathrm{~g}$ [40]. The results revealed that $C$. roseus and A. aspera are rich sources of phenolic and flavonoids. The reported traditional usage of these plants can be attributed to these phenolic and flavonoids content. Variation of TPC and TFC from plants to plants and parts to parts can be justified as the fact that the time of maturity at harvest, growing condition, soil condition, altitude of plant growth, and post-harvest treatment [41].

\section{DPPH free radical scavenging activity}

$\%$ DPPH free radical scavenging activity at different concentrations of ascorbic acid, A. aspera and C. roseus is tabulated below in table 3:

$\mathrm{MeOH}$ extract of leaves of $C$. roseus had the $\mathrm{IC}_{50}$ value of $49.74 \pm 0.52$ $\mu \mathrm{g} / \mathrm{ml}$ very close to the $\mathrm{IC}_{50}$ value of standard ascorbic acid $32.58 \pm 0.25$ $\mu \mathrm{g} / \mathrm{ml}$ than $\mathrm{IC}_{50}$ value of $A$. aspera i.e. $53.54 \pm 0.40 \mu \mathrm{g} / \mathrm{ml}$. table 4 . The antioxidant property of both plants might be due to the phytoconstituents such as flavonoids, polyphenols, acids, esters, alcoholic groups, etc. This result is comparable to the data reported previously. The previous data obtained revealed that the $100 \mu \mathrm{g} / \mathrm{ml}$ extracts of $C$. roseus possessed $45.7 \pm 3.4 \%$ inhibition in the methanolic extract [36]. DPPH assays at different concentrations (200 to $1000 \mu \mathrm{g}$ ) in methanol showed $81.70 \%$ at $800 \mu \mathrm{g}$ [34]. Antioxidant activity of extracts of $A$. aspera by DPPH showed $\mathrm{IC}_{50}$ of the ethanolic extract showed $556.07 \mu \mathrm{g} / \mathrm{ml}$ [15]. Its roots and leaves possessed $\mathrm{IC}_{50}$ values of $241.86 \mu \mathrm{g} / \mathrm{ml}$ and $129.91 \mu \mathrm{g} / \mathrm{ml}$, respectively [19].

\section{Alpha-amylase inhibition test}

Alpha-amylase inhibition \% values at different concentrations of standard acarbose and both plant extracts are shown in the below table 5 .

Table 3: \% inhibition of ascorbic acid, AA and CR at different concentrations

\begin{tabular}{llll}
\hline $\begin{array}{l}\text { Concentration } \\
(\boldsymbol{\mu} \mathbf{g} / \mathbf{m l})\end{array}$ & \% Inhibition & AA & CR \\
\cline { 2 - 4 } & Ascorbic Acid & $37.41 \pm 1.23$ & $39.31 \pm 0.85$ \\
40 & $49.48 \pm 1.21$ & $52.63 \pm 1.79$ & $51.75 \pm 1.30$ \\
60 & $75.51 \pm 0.92$ & $59.48 \pm 1.31$ & $62.01 \pm 1.37$ \\
80 & $80.52 \pm 1.08$ & $64.17 \pm 1.57$ & $70.43 \pm 1.48$ \\
100 & $90.08 \pm 1.47$ & $72.81 \pm 1.49$ & $77.78 \pm 1.04$ \\
\hline
\end{tabular}

Where $\mathrm{CR}=$ C. roseus and $\mathrm{AA}=$ A. aspera, Mean \% Inhibition are expressed as means $\pm \mathrm{SD}(\mathrm{n}=3), \mathrm{IC}_{50}$ values of the plant extracts along with the standard Ascorbic acid is tabulated below in table 4: 
Table 4: Comparison of IC 50 values of both extracts with ascorbic acid

\begin{tabular}{ll}
\hline Sample & IC $_{\mathbf{5 0}}(\boldsymbol{\mu g} / \mathbf{m l})$ \\
\hline Ascorbic acid & $32.58 \pm 0.25$ \\
A. aspera & $53.54 \pm 0.40$ \\
C. roseus & $49.74 \pm 0.52$ \\
\hline
\end{tabular}

$\mathrm{IC}_{50}$ values are expressed as mean $\pm \mathrm{SD}(\mathrm{n}=3)$

Table 5: \% Inhibition at different concentrations

\begin{tabular}{llll}
\hline $\begin{array}{l}\text { Concentration } \\
(\boldsymbol{\mu} \mathbf{g} / \mathbf{m l})\end{array}$ & \% Inhibition & AA & CR \\
\cline { 2 - 4 } & Acarbose & $13.09 \pm 0.65$ & $11.67 \pm 0.67$ \\
10 & $19.75 \pm 0.81$ & $24.76 \pm 0.43$ & $23.96 \pm 0.43$ \\
40 & $23.41 \pm 1.03$ & $31.61 \pm 0.60$ & $28.07 \pm 0.43$ \\
60 & $30.06 \pm 0.35$ & $36.48 \pm 0.64$ & $33.32 \pm 0.48$ \\
80 & $39.74 \pm 0.27$ & $38.61 \pm 0.67$ & $41.12 \pm 1.14$ \\
100 & $58.28 \pm 0.80$ & $49.33 \pm 0.62$ & $52.75 \pm 0.62$ \\
\hline
\end{tabular}

Where $\mathrm{CR}=$. roseus and $\mathrm{AA}=A$. aspera, Mean \% Inhibition are expressed as means $\pm \mathrm{SD}(\mathrm{n}=3), \mathrm{IC}_{50}$ values of both plant extracts along with the standard acarbose is tabulated below in table 6 :

Table 6: Comparison of $\mathrm{IC}_{50}$ values obtained from $\alpha$-amylase inhibition

\begin{tabular}{ll}
\hline Samples & $\mathbf{I C}_{\mathbf{5 0}}(\boldsymbol{\mu g} / \mathbf{m l})$ \\
\hline Acarbose & $68.13 \pm 0.46$ \\
AA & $97.60 \pm 1.11$ \\
CR & $94.05 \pm 1.18$ \\
\hline
\end{tabular}

Where $\mathrm{CR}=$ C. roseus and $\mathrm{AA}=$ A. aspera, Mean $\%$ Inhibition are expressed as means $\pm \mathrm{SD}(\mathrm{n}=3)$

Here, $\mathrm{IC}_{50}$ value of standard acarbose was found to be $68.13 \pm 0.46$ $\mu \mathrm{g} / \mathrm{ml}$. A. aspera and C. roseus showed $\alpha$-amylase inhibitory activity with $\mathrm{IC}_{50}$ value $97.6 \pm 1.11 \mu \mathrm{g} / \mathrm{ml}$ and $94.05 \pm 1.18 \mu \mathrm{g} / \mathrm{ml}$, respectively table 6 . The result of phytochemicals analysis supported the alphaamylase inhibitory activities of plant extracts. There was a dosedependent increase in percentage inhibitory activity against $\alpha$ - amylase by these two plant extracts. The results obtained here are in good correlation with previously reported results $[29,44]$.

Protein tyrosine phosphatase 1B inhibition activity

$\%$ inhibition value of PTP1B inhibition activity at different concentrations is shown in table 7.

Table 7 \% Inhibition of PTP1B at different concentrations

\begin{tabular}{llll}
\hline $\begin{array}{l}\text { Concentration } \\
(\boldsymbol{\mu} \mathbf{g} / \mathbf{m l})\end{array}$ & \% Inhibition & AA & CR \\
\cline { 2 - 4 } & Ursolic acid & $2.65 \pm 0.48$ & $2.33 \pm 0.82$ \\
10 & $52.98 \pm 0.84$ & $14.29 \pm 1.14$ & $11.92 \pm 0.79$ \\
20 & $57.11 \pm 0.95$ & $29.87 \pm 1.50$ & $35.23 \pm 0.87$ \\
35 & $65.79 \pm 0.73$ & $54.55 \pm 0.53$ & $51.29 \pm 1.27$ \\
70 & $89.53 \pm 0.70$ & $59.76 \pm 0.43$ & $57.72 \pm 1.39$ \\
\hline
\end{tabular}

Mean \% Inhibition are expressed as means $\pm \mathrm{SD}(\mathrm{n}=3)$, IC 50 values of the plant extracts along with the standard Ursolic acid is tabulated below:

Table 8: Comparison of IC 50 values obtained from PTP1B inhibition

\begin{tabular}{ll}
\hline Samples & $\mathbf{I C}_{\mathbf{5 0}}(\boldsymbol{\mu g} / \mathbf{m l})$ \\
\hline Ursolic acid & $13.58 \pm 0.23$ \\
AA & $48.72 \pm 0.46$ \\
CR & $50.21 \pm 1.03$ \\
\hline
\end{tabular}

Where $\mathrm{CR}=$ C. roseus and $\mathrm{AA}=A$. aspera, $\mathrm{IC}_{50}$ values are expressed as mean $\pm \mathrm{SD}(\mathrm{n}=3)$

IC $_{50}$ value of standard ursolic acid was found to be $13.58 \pm 0.23 \mu \mathrm{g} / \mathrm{ml}$. A. aspera showed higher PTP1B inhibitory activity with $\mathrm{IC}_{50}$ value $48.72 \pm 0.46 \mu \mathrm{g} / \mathrm{ml}$ table 8 . A higher amount of saponin, reducing sugars, and glycoside in a phytochemical test is in agreement with this result. To the best of our knowledge, there are no previous reports related to the PTB1 inhibitory activity of $A$. aspera was exhibited.

Whereas $C$. roseus leaf extract has $\mathrm{IC}_{50}$ value $50.21 \pm 1.03 \mu \mathrm{g} / \mathrm{ml}$. The result is well supported by published results $[44,45]$. Priyanka et al. reported that 3-nitrophthalic acid present in C. roseus methnolic extract might be responsible for PTB1B inhibition activity by Docking and by applying "Lipinski Rule of Five" on ligands [47].

The GC analysis of hexane fraction extracted from methanolic extract of $A$. aspera coupled with mass library search facilitated the identification of 14 different peaks constituting $99.99 \%$ area, 8 compounds were identified with more than $90 \%$ accuracy (matching factor), constituting $77.52 \%$ of the total area fig. 5. The 
majority of compounds identified were fatty acids, esters of fatty acids, and hydrocarbons. The major phytochemicals analyzed in the hexane fraction of methanolic extract of $A$. aspera leaves along are tabulated in table 9.

The literature revealed that $n$-Hexadecanoic acid belonging to the Palmitic acid family possessed antioxidant, hypocholesterolemic, nematicide, pesticide, lubricant antiandrogenic properties.
Hexadecanoic acid, ethyl ester belonging to fatty acid ester, has similar properties and acts as a 5-Alpha reductase inhibitor. Phytol is a diterpene having antimicrobial, anti-inflammatory, anticancer, and diuretic activities. 9,12-Octadecadienoic acid, methyl ester has the properties of anti-inflammatory, hypercholesterolemic, cancer preventive, hepatoprotective, nematicide, insectifuge, antihistamine, antieczemic, anti-acne, 5-alpha reductase inhibitor, antiandrogenic, anti-arthritic, anti-coronary [46].

\section{GC-MS Analysis of hexane extract of A. aspera}

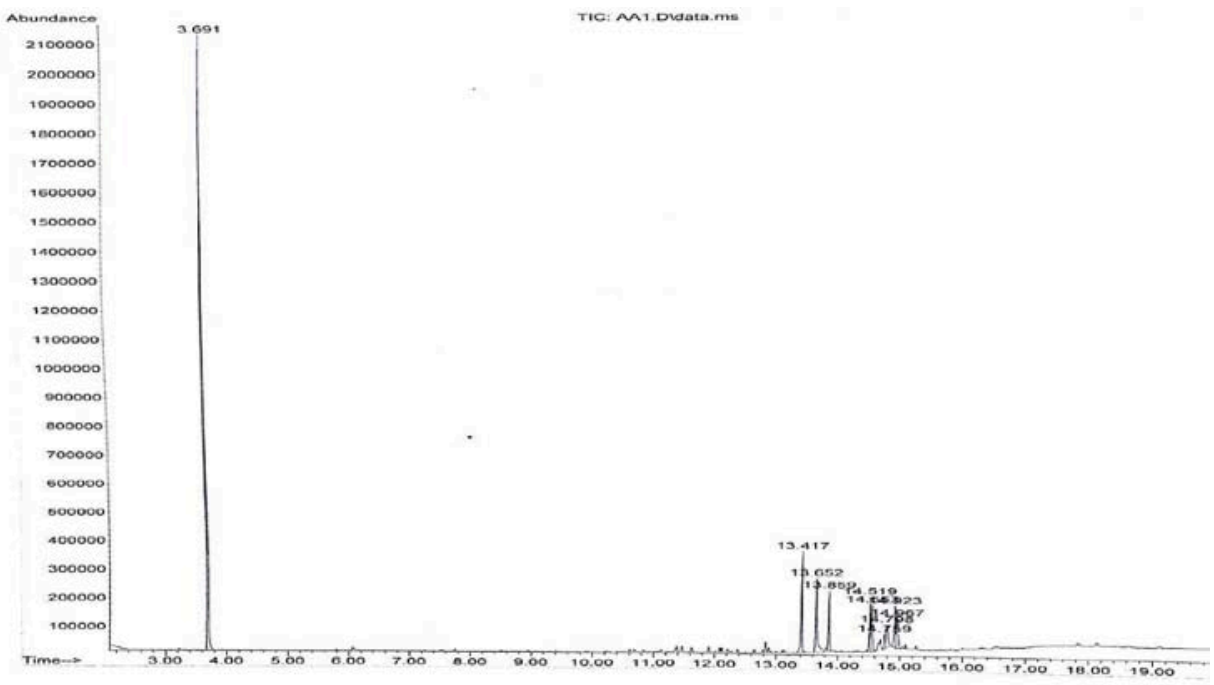

Fig. 5: GC Chromatogram of AA leaves

Table 9: Compounds identified in the hexane extract of $A$. aspera leaves

\begin{tabular}{|c|c|c|c|c|c|}
\hline S. No. & Area \% & $\begin{array}{l}\text { Retention time } \\
\text { (min) }\end{array}$ & Compound name & $\begin{array}{l}\text { Molecular } \\
\text { formula }\end{array}$ & Molecular weight \\
\hline a. & 28.80 & 13.417 & n-Hexadecanoic acid & $\mathrm{C}_{16} \mathrm{H}_{32} \mathrm{O}_{2}$ & 256 \\
\hline b. & 15.93 & 13.652 & Hexadecanoic acid, methyl ester & $\mathrm{C}_{17} \mathrm{H}_{34} \mathrm{O}_{2}$ & 270 \\
\hline c. & 9.64 & 13.859 & Hexadecanoic acid, ethyl ester & $\mathrm{C}_{18} \mathrm{H}_{36} \mathrm{O}_{2}$ & 284 \\
\hline d. & 4.09 & 14.519 & 9,12-Octadecadienoic acid, methyl ester & $\mathrm{C}_{19} \mathrm{H}_{34} \mathrm{O}_{2}$ & 294 \\
\hline e. & 5.26 & 14.563 & $9,12,15$-Octadecatrienoic acid, methyl ester & $\mathrm{C}_{19} \mathrm{H}_{32} \mathrm{O}_{2}$ & 292 \\
\hline f. & 8.06 & 14.661 & Phytol & $\mathrm{C}_{20} \mathrm{H}_{40} \mathrm{O}$ & 296 \\
\hline g. & 1.76 & 14.694 & Octadecanoic acid, methyl ester & $\mathrm{C}_{19} \mathrm{H}_{38} \mathrm{O}_{2}$ & 298 \\
\hline h. & 3.98 & 14.923 & Linoleic acid, ethyl ester & $\mathrm{C}_{20} \mathrm{H}_{36} \mathrm{O}_{2}$ & 308 \\
\hline
\end{tabular}

\section{GC-MS Analysis of $C$. roseus}

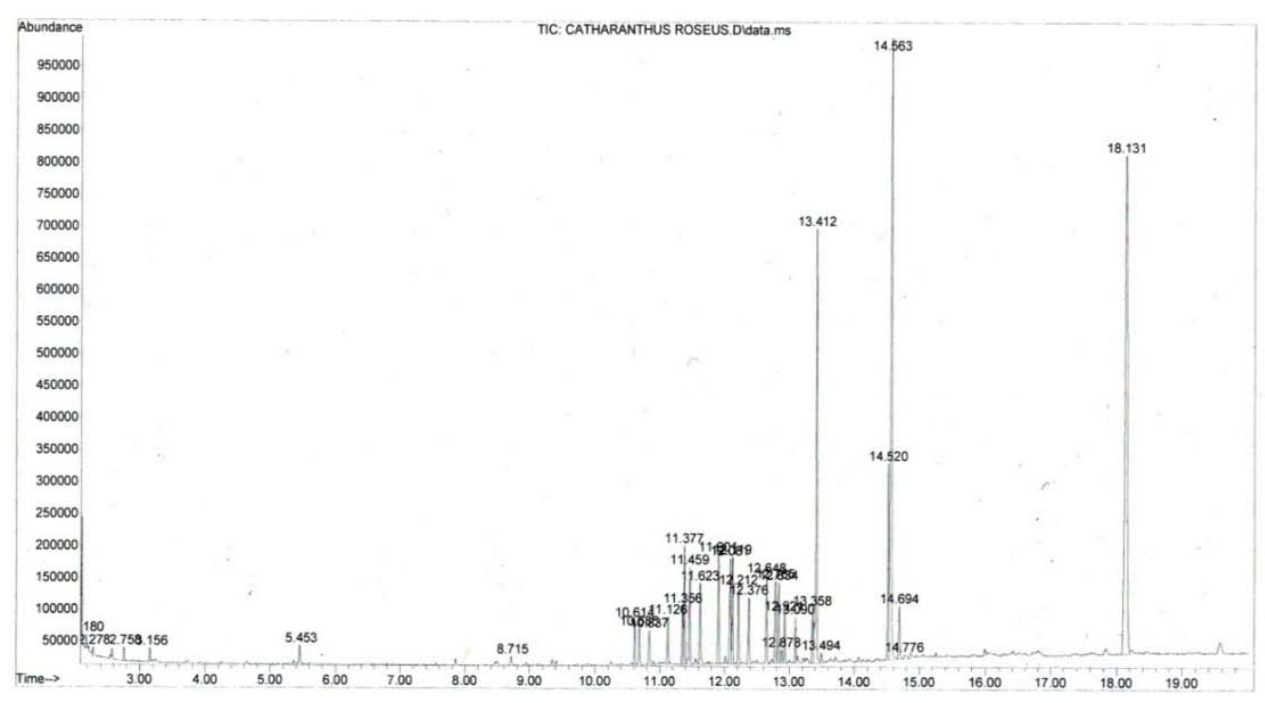

Fig. 6: GC chromatogram of the hexane extract of $C R$ leaves 
The GC chromatogram analysis of hexane fraction from methanolic extract of $C$. roseus coupled with mass NIST 08 library search facilitated the identification of 13 different peaks corresponding to the 13 different compounds constituting $100.01 \%$ peak area and out of these peaks, 6 compounds were identified with more than $90 \%$ accuracy (matching factor), constituting $76.69 \%$ of the total peak area percentage. The majority of compounds identified were fatty acids, esters of fatty acids and a few of them were hydrocarbons.

A list of six compounds is presented in table 10, along with their area \%, retention time, molecular formula, and molecular weight.

Table 10: Compounds identified in the hexane extract of $C$. roseus

\begin{tabular}{|c|c|c|c|c|c|}
\hline S. No. & Area\% & Retention time (min) & Compounds & Formula & Molecular weight \\
\hline a. & 9.74 & 11.476 & Hexadecanoic acid, methyl ester & $\mathrm{C}_{17} \mathrm{H}_{34} \mathrm{O}_{2}$ & 270 \\
\hline b. & 4.79 & 11.906 & n-Hexadecanoic acid & $\mathrm{C}_{16} \mathrm{H}_{32} \mathrm{O}_{2}$ & 256 \\
\hline c. & 4.80 & 14.520 & 9,12-Octadecadienoic acid, methyl ester, & $\mathrm{C}_{19} \mathrm{H}_{34} \mathrm{O}_{2}$ & 294 \\
\hline d. & 1.34 & 14.694 & Octadecanoic acid, methyl ester & $\mathrm{C}_{19} \mathrm{H}_{38} \mathrm{O}_{2}$ & 298 \\
\hline e. & 29.92 & 14.563 & $9,12,15$-Octadecatrienoic acid, methyl ester, & $\mathrm{C}_{16} \mathrm{H}_{32} \mathrm{O}_{2}$ & 292 \\
\hline f. & 26.10 & 18.131 & $\begin{array}{l}\text { 1, 2-Benzenedicarboxylic acid, mono( } 2 \text { - } \\
\text { ethylhexyl) ester }\end{array}$ & $\mathrm{C}_{16} \mathrm{H}_{23} \mathrm{O}_{4}$ & 279 \\
\hline
\end{tabular}

\section{CONCLUSION}

The present study has shown that the methanolic extract of the leaves of $A$. aspera and $C$. roseus has remarkable antioxidant potential and inhibitory activity of the $\alpha$-amylase and PTP $1 \mathrm{~B}$ enzymes. These effects would be due to its important phenolic composition, whose quantitative study has revealed the varied presence of polyphenols and flavonoids. These results could justify the use of these plants in traditional medicine for the treatment of type 2 diabetes and complications. Study of chemical constituents of these plants using sophisticated technologies like NMR, HPLC, etc. can provide a way for extensive research that can be used for commercial drug production with lesser or no side effects.

\section{ACKNOWLEDGMENT}

This research work was supported by "the UGC master research support" grant from University Grant Commission, Nepal. The authors are thankful to the respected Prof. Dr. Megh Raj Pokhrel, former Head of the Central Department of Chemistry, Tribhuvan University, for providing laboratory services to conduct this research work.

\section{AUTHORS CONTRIBUTIONS}

B. Subba analyzed the data, and wrote the manuscript, supervise, whereas Yashoda Karki carried out the laboratory work under the guidance of Dr. Deegendra Khadka (PTP1B inhibition assay). All authors read and approved the final manuscript.

\section{CONFLICT OF INTERESTS}

All authors have none to declare.

\section{REFERENCES}

1. American Diabetes Association. Diagnosis and classification of diabetes mellitus. Diabetes Care 2009;32 Suppl 1:S62-7.

2. Gurzov EN, Stanley WJ, Brodnicki TC, Thomas HE. Protein tyrosine phosphatases: molecular switches in metabolism and diabetes. Trends Endocrinol Metabol 2014;15:1-10.

3. Alonso A, Sasin J, Bottini N, Friedberg I, Friedberg I, Osterman A, et al. Protein tyrosine phosphatases in the human genome. Cell 2004;117:699-711.

4. Hameed I, Masoodi SR, Mir SA, Nabi M, Ghazanfar K, Ganai BA. Type 2 diabetes mellitus: From a metabolic disorder to an inflammatory condition. World J Diabetes 2015;6:598-601.

5. Mbikay M. Therapeutic potential of Moringa oleifera leaves in chronic hyperglycemia and dyslipidemia: a review. Frontiers Pharm 2012;3:1-12.

6. Nguyen PH, Zhao BT, Ali MY, Choi JS, Rhyu DY, Min BS, et al. Insulin-mimetic selaginellins from Selaginella tamariscina with protein tyrosine phosphatase 1B (PTP1B) inhibitory activity. J Nat Prod 2015;78:34-42.

7. Sun J, Qu C, Wang Y, Huang H, Zhang M, Li H, et al. PTP1B, a potential target of type 2 diabetes mellitus. Mol Biol 2016;5:1-6.

8. Quang TH, Thi N, Ngan T, Yoon C, Cho K, Kang DG, et al. Protein tyrosine phosphatase $1 \mathrm{~B}$ inhibitors from the roots of Cudrania tricuspidata. Molecules 2015;1:11173-83.
9. Chintoju N, Konduru P, Kathula RL, Remella R. Importance of natural products in modern history. Res Rev J Hosp Clin Pharm 2015;1:5-10.

10. Mishra JN, Verma NK. A brief study on Catharanthus roseus: a review. Int J Res Pharma Sci 2017;2:20-3.

11. Tamrakar AK, Maurya CK, Rai AK. PTP1B inhibitors for type 2 diabetes treatment: a patent review (2011-2014). Expert Opin Ther Pat 2014;24:1101-15.

12. Kafle B, Cho HJ. Isoxazolone derivatives as potent inhibitors of PTP1B. Bull Kor Chem Soc 2012;33:275-7.

13. Kunwar RM, Uprety Y, Burlakoti C, Chowdhary CL, Bussmann CW. Indigenous use and ethnopharmacology of medicinal plants in Far-West Nepal. Ethnobot Res Appl 2009;7:25-8.

14. Shrestha PM, Dhillion SS. Medicinal plant diversity and use in the highlands of dolakha district, Nepal. J Ethnopharmacol 2003;86:81-96.

15. Subba B, Srivastav C, Kandel RC. Scientific validation of medicinal plants used by Yakkha community of Chanuwa VDC, Dhankuta, Nepal. Springerplus 2016;5:155.

16. Srivastav S, Singh P, Mishra G, Jha KK, Khosa RL. Achyranthus aspera-an important medicinal plant: a review. J Nat Prod Plant Resour 2011;1:1-14.

17. Ghimire K, Banerjee, Gupta A, Dahal P. Phytochemical constituents and pharmacological uses of medicinal plant Achyranthes aspera: a review. World J Pharm Res 2014;4:470-89.

18. Priya CL, Kumar G, Karthik L, Rao KVB. Antioxidant activity of Achyranthes aspera Linn stem extracts. Pharmacologyonline 2010;2:228-37.

19. Edwin S, Jarald EE, Deb L, Jain A, Kinger H, Dutt KR, et al. Wound healing and antioxidant activity of Achyranthes aspera. Pharm Biol 2008;46:824-8.

20. Rani N, Sharma SK, Vasudeva N. Assessment of antiobesity potential of Achyranthes asperalinn. seed. J Evidence Based Complementary Altern Med 2012;2012:1-7.

21. Pereira DM, Valentão P, Sottomayor M, Ferreres F, Andrade PB. Phenolic Compounds in Catharanthus roseus. J Nat Products 2013;2:2093-106

22. Tolambiya P, Mathur S. A study on potential phytopharmaceuticals assets in Catharanthus roseus L. (Alba). Int J Life Sci Biotechnol Pharma Res 2016;5:1-6.

23. Lalitha P, Jayanthi P. Preliminary studies on phytochemicals and antimicrobial activity of solvent extracts of Eichhornia crassipes (Mart.) Solms. Asian J Plant Sci Res 2012;2:115-22.

24. Pradeepa M, Kalidas V, Geetha N. Qualitative and quantitative phytochemical analysis and bactericidal activity of Pelargonium graveolens L'her. Int J Appl Pharm 2016;8:7-11.

25. Pisutthanan S, Plianbangchang P, Pisutthanan N, Ruanruay S, Muanrit 0 . Brine shrimp lethality activity of Thai medicinal plants in the family Meliaceae. Naresuan Univ J 2004;12:13-8.

26. Mobarak SA, Hossain S, Mia S. Microbicidal and cytotoxic actions of methanolic crude extracts of Ammannia multifloraroxb. Int J Curr Pharm Sci 2015;7:54-6.

27. Meyer AS, Yi OS, Pearson DA, Waterhouse AL, Frankel EN. Inhibition of human low-density lipoprotein oxidation in relation to the composition of phenolic antioxidants in grapes (Vitis vinifera). J Agric Food Chem 1997;45:1638-43. 
28. Arun N, Ragunathan MG, Jayanthi J. Antioxidant activity, total phenol, flavonoid, alkaloid, tannin, and saponin contents of leaf extracts of Salvinia molesta D. S. Mitchell. Asian J Pharm Clin Res 2016;9:185-8.

29. Paudel B, Bhattarai HD, Kim IC, Lee H, Sofronov R, Ivanova L, et al. Estimation of antioxidant, antimicrobial activity and brine shrimp toxicity of plants collected from oymyakon region of the Republic of Sakha (Yakutia), Russia. Biol Res 2014;47:1-6.

30. Jebitta R, Allwin J. Antioxidant activity, total phenol, flavonoid, and anthocyanin contents of Jamun (Syzygium cumini) pulp powder. Asian J Pharm Clin Res 2016;9:361-3.

31. Bhutkar MA, Bhise SB. In vitro assay of alpha-amylase inhibitory activity of some indigenous plants. Int J Chem Sci 2012;10:457-62.

32. De Sales PM, de Souza PM, Simeoni LA, Magalhães P, de O, Silveira D. $\alpha$-amylase inhibitors: a review of raw material and isolated compounds from plant source. J Pharm Pharm Sci 2012;15:141-83.

33. Na B, Nguyen PH, Zhao BT, Vo QH, Min BS, Woo MH. Protein tyrosine phosphatase 1B (PTP1B) inhibitory activity and glucosidase inhibitory activity of compounds isolated from Agrimonia pilosa. Pharm Biol 2016;54:474-80.

34. Kafle B, Aher NG, Khadka D, Park H, Cho H. Isoxazol-5(4H)one derivatives as PTP1B inhibitors showing an anti-obesity effect. Chem Asian J 2011;5:2073-9.

35. Patharajan S, BalaAbirami S. Antioxidant activity and phytochemical analysis of fractionated leaf extracts of Catharanthus roseus. Int J Pharm 2014;1:138-43.

36. Kamble A. Phytochemical studies on Achyranthes aspera. Sci Res J 2018;100:16-34.

37. Akhtar N, Ihsan-ul-Haq, Mirza B. Phytochemical analysis and comprehensive evaluation of antimicrobial and antioxidant properties of 61 medicinal plant species. Arab J Chem 2015;11:1223-35.
38. Hossain MJ, Khaleda L, Chowdhury MA, Arifuzzaman M, AlForkan. Phytochemical screening and evaluation of cytotoxicity and thrombolytic properties of Achyranthes aspera leaf extract. J Pharm Biol Sci 2013;6:30-8.

39. Aziz S, Saha K, Ahmed U, Parveen S, Ahmed N. Comparative studies on cytotoxic, antibacterial and free radical scavenging activity among different extracts of leaves and flowers of Catharanthus roseus available in Bangladesh. Int J Pharm Phytopharmacol Res 2014;4:169-72.

40. Kumar A, Singhal KC, Sharma RA, Vyas GK, Kumar V. Analysis of antioxidant activity of Catharanthus roseus L. and its association with habitat temperature. Asian J Exp Biol Sci 2013;4:155-8.

41. Pereira DM, Faria J, Gaspar L, Ferreres F, Valentão P, Sottomayor $\mathrm{M}$, et al. Exploiting Catharanthus roseus roots: source of antioxidants. Food Chem 2010;121:56-61.

42. Inder M, Saggoo S. Screening of total phenol and flavonoid content in different cytotypes of two species of Achyranthes linn. from western Himalaya, India. Int J Pharm Pharm Sci 2017;9:205-10.

43. Rama P, Vignesh A, Lakshmanan G, Murugesan K. In vitro antioxidant activity of Achyranthes aspera linn. Int J Med Pharm Sci 2013;3:67-78.

44. Bhattecharjee D, Das A, Das SK, Chakraborthy GS. Clerodendrum infortunatum linn.: a review. J Adv Pharm Healthcare Res 2011;1:82-5.

45. Malathi V, Devi SS, Revathi K. Antidiabetic activity by the in vitro alpha-amylase and alpha-glucosidase inhibitory activity of Catharanthus roseus. Bioscan 2010;5:655-9.

46. Chattopadhyay RR. A comparative evaluation of some blood sugar lowering agents of plant origin. J Ethnopharmacol 1994;67:367-72.

47. Tolambiya $\mathrm{P}$, Mathur. Identification of cost-effective drug through in silico approach of Catharanthus roseus plant ligandreceptor docking for type 2 diabetes. World J Pharm Pharm Sci 2017;6:1029-49. 